\title{
The Canadian Jewish Community Serving Newcomers
}

\author{
John Morris
}

\begin{abstract}
The Jewish Community is the oldest non-governmental agency serving newcomers in Canada. Its emphasis has been on employing professional, secular social work practice. This paper reports on conversations held with the Jewish Immigrant Aid Society (JIAS) staff, board members, clients and sponsors. Focus group meetings were held with clients and sponsors in nine Canadian cities from Ottawa to Vancouver. Highlighted are the conclusions that sponsors and clients have arrived at regarding services the Jewish community offers.

\section{Précis}

La communauté juive est la plus ancienne agence non-gouvernementale desservant les nouveaux arrivants au Canada. Son point fort a toujours consisté dans la mise en pratiques de procédures de travail social séculaires. Le présent article rapporte des conversations tenus avec du personnel, des membres $d u$ comité de direction, des bénéficiaires, et des commanditaires de la Socisté d'Aide aux Juifs immigrants. Des sinces de discussions en groupe ont eut lieu avec des bénéficiaires, et commandilaires dans neufs villes canadiennes d'Ottawa d Vancouver. L'attention porte principalement sur les conclusions tirées par les bénéficiaires, et commanditaires face aux services assurés par la communauté juive.
\end{abstract}

The Jewish Community in Canada has a long history of involvement in Jewish immigration. Almost as hisțoric are

John Morris, Ph.D., is a faculty member at Nipissing University, North Bay, Ontario. Research reported in this paper was supported through the Social Science and Humanities Research Council of Canada, the Centre for Refugee Studies, Resettlement Unit, and a grant from Nipissing Unioersity's Research Grants Committee.
Jewish settlement services offered as professionalized services to Jewish Newcomers to Canada (Kage 1962). Settlement services are provided by the Jewish Immigrant Aid Society (JIAS) and is the focus of attention in this paper.

In the spring of 1994, I was asked to assist the organisation in coming toward a better understanding of the meaning of equitable service across the country; to help establish a minimum level of service that all Jewish communities should attain in their settlement activities. JIAS is a unique organisation in Canada - in contrast to other faith communities-in that it acts as a national policy and administrative body. It also has a direct presence as a service agency in Toronto and Montreal, and provides funding to agencies-usually Jewish Family Services (JFS)-in smaller cities to provide settlement services to newcomers. JIAS is the oldest aid agency in Canada, chartered by the Government in offering a support services that parallels Provincial welfare support.

This paper provides an overview highlighting the results of a Canada wide survey of clients, sponsors, staff and Board Members of JIAS. Added to conventional research reporting, methodology, observations and analysis is a discussion of religious obligations toward newcomers/strangers as detailed in Judaic holy texts. Doctrinal concerns aside, JIAS' head office, "JIAS National's," concerns about equity of service across Canada is outlined in the section entitled "Background to the Research." Analysis is organised in three sections: importance of jobs, listening to needs, and communities welcoming strangers.

Canada's Jewish immigrant communities are mythical in Canadian consciousness with images extending back a half century: The Main in Montreal, Spadina in Toronto, and the
North end of Winnipeg. Jewish immigration to Canada continues to increase the size of Canadian Jewry though images of the concentrated settlement has dissipated. Over 30,000 Jews immigrated to Canada in the ten years period from 1981-1991.

Jewish immigrants arrive by proportion to the size of existing Jewish communities. Large numbers of immigrants settle where large communities exist, and smaller numbers settle in smaller communities. Of these arrivals in the period between 1981-1991, a third came from Eastern Europe and the Soviet Union. Another 20 percent came from Israel. Twenty-five percent came with English as a first language originating from either the United States or South Africa, (14\% and 11\% respectively). The remaining 25 percent came from Europe/Scandinavia (9\%) and Northern Africa including Morocco, Algeria and Tunisia (7\%) with the balance originating in small percentages from other parts of the world. ${ }^{1}$

This immigration represents 9 percent of the Canadian Jewish community (totalling 303,000 people), a trend of long standing. Consequently, 15 percent of all Jews in Canada arrived in the past 20 years, an immigrant/native born ratio that is double that of Canadian society as a whole. This ratio is perhaps out of proportion with the number of strangers that a Jewish community expects to be in their presence based on religious history. Accordingly, it is difficult for Canada's Jewish community to meet rabbinical instructions on the treatment of strangers.

\section{Judaic Ethics and Strangers}

The Jewish Community in Canada has a remarkable record of helping Jewish newcomers to Canada. It has funded JIAS as an institution becoming a societal leader in the use of professional social workers to provide services to 
newcomers. Through professionalization-a secular phenomenonthere has been perhaps less pressure on the organisation to consider its mandate and mission in theological and doctrinal terms. This contrasts with other agencies from the Christian faith (Mennonite and Catholic) that do the landscape of service providers in the same cities where Jewish communities serve newcomers. There, much time seems to be spent on clarifying and tying mission statements to theology, and is, from the perspective of faith and organisational direction, a valuable use of resources (Morris 1995).

In ancient Israel the closest category to what we now consider immigrants and refugees was "resident foreigners," or in Hebrew gerim, the protected stranger. Prior to the Exodus, resident aliens, as a class, was unknown in Israel. Aliens went with them when they left Egypt (Ex. 12: 38, 48), non-Jews who identified with the Israelites' quest for freedom. Later, during the conquest of Canaan, the numbers of these aliens further increased (Jos. 9: 3). Beyond the Canaanites others numbered among them; foreigners who sought refuge in times of drought and famine (cf. Ruth 1:1) and those who fled before invading armies (Judaica Encyclopaedia 1972, 220). They were not slain as Deuteronomy commands (cf. e.g. 7: 2) nor reduced to total slavery (cf. 1 Kings 5: 29; II Chronicles 2: 1617).

Protected aliens could not own land as this belonged to the Israelites (cf. Lev. 25: 23-24). Consequently they worked as day labourers and artisans (Deut. 24: 14-15; cf. 29: 10). Sacred books-the Book of the Covenant and the Decalogue-class the gerim among those who were dependent, they were "your strangers." Most of them were quite poor and were therefore permitted to share in the fallen fruit in the vineyard (Lev. 19: 10), the edges of the field, and the gleanings of the harvest (Lev. 23: 22), all of which were regular provisions for the poor.

To recall the sufferings of the Israelite experience in Egypt, and to befriend gerim as one of their own, is a profoundly moral and just act. The imperative of Tikun Olam (mending the world) is a responsibility of all Jews and manifests as social justice, forms one of the guiding principles of Jewish law, philosophy, values and behaviour. In considering care for the poor, it should be carried out with a view toward redressing some of the imbalance in society (Canadian Council for Reform Judaism 1994). Helping those in need is not a matter of choice in Jewish tradition-it is a matter of law (ibid.).

The way in which assistance is given is as important, in Judaism, as that which is given. Respect for human dignity must pervade all aspects of giving. It is best to give anonymously to safeguard the feelings of those in need at all times. Further, Jewish ethics call for early action for those in need. A person's dignity should not be put at risk before the community intervenes and provides assistance (ibid.).

Most relevant for recent Jewish arrivals, are questions of how well they should be maintained? And what is the responsibility of newcomers to the community? On the question of "what level should newcomers be maintained?" is a command from Deuteronomy:

If there is a needy person among you ... do not harden your heart and shut your hand against your needy kinsman. Rather, you must open your hand and lend him sufficient [emphasis added] for whatever he needs.

Give to him readily and have no regrets when you do so, for in return the Lord your God will bless you in all your efforts and in all your undertakings. For there will never cease to be needy ones in your land, which is why I command you; open your hand to the poor and needy kinsman in your land. (Deuteronomy 15: 7-11)

This passage makes clear that to give is an imperative action. What is left unclear is how to interpret "sufficient." In their deliberations the Sages of the Talmud conclude that "sufficient" means that it is best to maintain the poor according to their previously accus- tomed lifestyle. Yet, where the previous lifestyle is excessive-or beyond the wealth of the host communitythen there is a moral obligation for the recipients to defer to the community (Linzer 1990, 122).

\section{Services across the Country}

Jewish Community Services across Canada are not uniform. Nor are the number of newcomers to Canadian cities uniform to the size of Jewish communities in those cities. Beyond Toronto and Montreal with communities in the order of 150,000 and 100,000 people respectively, the next largest communities are much smaller. Vancouver has the third largest Jewish community with only 14,000 people calling themselves religious Jews. In larger cities a general trend can be observed: the number of newcomers is proportional to the size of the community. As cities become smaller, however, the pattern becomes more volatile making the burden of caring for newcomers in these places more onerous. Consider Edmonton and Windsor, as is shown in Table 1 . These small communities have disproportionately more newcomers for whom to care.

In Toronto and Montreal, where JIAS has its own agencies, refugee claimants can take advantage of group services for psychosocial support. The National Board of JIAS would like to extend some version of this kind of service to refugees so that they might improve their initial years in Canada wherever they locate, and hopefully stay in these cities. A broad range of general services do exist in most cities. In a 1992 survey, it was found that most agencies outside Toronto and Montreal offer most of the range of services found in these larger centres, at least some of the time, if not always (JIAS 1992). Services were grouped in three categories: immigration, integration and acculturation. Immigration is used to refer to newcomer's arrival; integration-which is of most direct concern to JIAS-refers to newcomers' first two years in Canada, and acculturation refers to resettling that occurs after two 
Table 1: Jewish Communities, and Numbers of Newcomers in Cities Studied

\begin{tabular}{lcccc}
\hline City & $\begin{array}{c}\text { Population } \\
1991\end{array}$ & $\begin{array}{c}\text { Jewish } \\
\text { Population } \\
1991\end{array}$ & $\begin{array}{c}\text { JIAS New } \\
\text { Immigrant Clients (NIC) } \\
\text { 1992 }\end{array}$ & $\begin{array}{c}\text { Proportion of NIC } \\
\text { to the size of } \\
\text { Jewish Population }\end{array}$ \\
\hline Toronto & $3,893,046$ & 151,115 & 2,627 & 0.0174 \\
Montréal & $3,127,242$ & 96,715 & 1,148 & 0.0119 \\
Vancouver & $1,602,502$ & 14,365 & 173 & 0.0120 \\
Winnipeg & 652,354 & 13,325 & 142 & 0.0107 \\
Ottawa-Hull & 920,857 & 9,915 & 48 & 0.0048 \\
Calgary & 754,033 & 5,455 & 38 & 0.0070 \\
Edmonton & 839,924 & 4,045 & 81 & 0.0200 \\
London & 381,522 & 2,195 & 9 & 0.0041 \\
Windsor & 262,075 & 1,560 & 45 & 0.0288 \\
Total & $13,033,315$ & 305,141 & 4,387 & \\
\hline
\end{tabular}

Source: Population statistics from Statistics Canada, JIAS clients from JIAS national.

year in Canada. Acculturation is considered to be out of JIAS' purview. After two years of stay in Canada, newcomers must seek services from Jewish Family Services (JFS). This is a moot point in cities other than Toronto and Montreal as JFS is already responsible for all three functions: immigration, integration and acculturation.

\section{Background to the Research}

Since the late 1980s, there has been a directive in JIAS, as mandated by a National Taskforce report, to bring equity in service delivery across the country, and to advocate for the entire Canadian Community with regard to immigration and refugee policy (Davis 1994). The task of ensuring equitable service across Canada is made difficult by a discontinuous organisational structure: In Montreal and Toronto JIAS fully funds front-line agencies; in every other major urban centre JIAS provides inadequate funding to assist JFS to provide immigrant services in addition to their more general social work case load.

A questionnaire mailed to JFS and JLAS agencies was completed in late
1992 by member agencies. It shows that services offered across the country were based on need, and on the resources and interest found in the Jewish Communities in these cities. In many centres the low numbers of incoming immigrants did not warrant continuous, robust programming. This lack of formal programming means that it is difficult to compare services across the country. Further, the understaffed nature of virtually all service agencies means that it is very difficult to warrant spending time on data collection of service provider activities when staff time is so valuable to actual service provision. Alternatively, such information is crucial to JIAS' effective planning and budget formulating processes.

The Board of JIAS, through its executive director Susan Davis, have undertaken several initiatives over the past few years to come to a better understanding of services offered across the country. With different initiatives occurring each year, five separate efforts have been made to try to gather service provision information. The most recent of these is the research re- ported on in this paper. These initiatives have been conducted to improve the information available for budget and operations decision-making.

\section{Methodology}

This paper brings together highlights of conversations that were held with staff, clients, sponsors and JIAS Board Members. ${ }^{2}$ These conversations were held in eight different cities in the following order: Ottawa, Vancouver, Calgary, Edmonton, Winnipeg, Toronto, Windsor, and Montreal between November 1994 and January 1995. Conversations with staff, clients and sponsors were held as focus group sessions. Staff meetings were held during the day, while meetings with clients and sponsors were held during the evening. Most focus group sessions lasted between one and a half and two hours and were held in English. Clients and sponsors were paid $\$ 25$ for their attendance.

Questions that predominated the research sessions included: "Are services across the country equitable for newcomers?", "How could services be made more equitable across the coun- 
try?", "What is a fair formulae to use in deciding the distribution of funding to JFS offices across the country?" Clients and sponsors were essentially asked the same questions. A hybrid of questions were developed based on research carried out in Montreal, and on research conducted by JIAS in 1992. There were some trials and errors used to ask questions that seemed to sustain a conversation and elicit comments. Very general questions were used first:

If a relative of yours just arrived in the city, how would you describe JFS/ JIAS services to them? Would you give them a recommendation to come to use these services? Were the services worthwhile to the point where you feel comfortable recommending them to someone else?

Do you know newly arrived Jewish immigrants that JIAS is not reaching? Do you have suggestions as to how we can reach them?

What has pleased you the most about your experience with JIAS?

What has displeased you the most about your experience with JIAS?

How could your experience with JFS/ JIAS have been improved?

What services or programs would you want to see which do not presently exist? How easy or difficult is it to understand and get access to the programs and services which JIAS tells you about, or which you request?

Do you have friends or relatives that you would like to join you in this city? Have you discussed it with someone at JIAS? If yes, what was the response?

Board Members and staff were asked similar, but not exactly the same set of questions. For Board Members questions were organised so as to elicit information under the following headings: big cities and small cities; role in the local agency; important issues; vocational services; relations with JIAS National; relations with the main funder; political and religious issues; mandate; sharing service provision; and prospects for the future.

Staff meetings had to be more disciplined as I needed to collect information on a certain core of information. Questions asked were organised under the following headings: services; demand for services; newcomers joining the Jewish Community; evaluation; funding; services available in the city; sharing service provision; cutbacks; relations with JIAS National; attracting and keeping newcomers;job security and working conditions and important issues. Often it would be impossible to get answers to the questions in the allotted two hours. Some questions were dropped as the study continued, but these were more peripheral to the understanding sought.

Focus groups were organised by staff in each city. While I put into place guidelines for who should be invited to focus groups-to get a range of experience and relationships to the agency-these guidelines were not always followed. For the most part, however, it seemed that participants provided a variety of experiences save for the voices of seniors, and youth. The format of an evening focus group was simply inappropriate to seniors and youth.

\section{Observation}

After visiting two cities-Ottawa and Vancouver-I reaffirmed that the task of trying to draw together information that would constitute a meaningful comparison between places is not possible. The main difficulty in doing this is in language, and in trying to come to an understanding in each individual case about the components that comprise a generic program. Many agencies, for example, have developed a "family to family program." Yet,Ihave found that the program title gives little more information in terms of standards than a general intent to link families; there are no assumed standards of how often the families will meet, or the kinds of activities in which the families will engage. While such standardisation based on titles is not desirablebecause local flexibility would be lost-this example does point to the need for a protocol for describing agency programs so that others-including clients, Board Members, and other agencies-can assess what the program actually does.

\section{Analysis}

There is a contradiction between what sponsors and clients say they value as important compared with JIAS/JFS social workers. Clients and sponsors are mostly concerned about jobs as is detailed in the first part of this analysis. This is followed by a contention by clients and sponsors that they need to be listened to more as well as highlighting some of the creative solutions that have been provided by agencies. Finally, issues of acceptance of newcomers by the local Jewish community is reviewed.

\section{The Importance of a Job}

Newcomers place highest priority on their first job relative to other services available. "The first job is more important than furniture, an apartment, etceteras. The first job provides dignity." Another former refugee agrees adding "It is also the hardest thing to find." In the past few years, with a weak Canadian economy, there has been little economic growth, and consequently little demand for newcomers who need to enter the economy. The restructuring of the Canadian economy has hit professionals particularly hard, making the heavily professionalized newcomer group of those from the former Soviet Union and Bosnia hard to employ in their chosen professions.

In one focus group words of experience are offered by two immigrants who have been in Canada for over ten years: success in the Canadian economy is based on persistence, perspiration, and patience. Another tells of his experience as an engineer. As an employment strategy, he decides not to take the Professional Engineers' designation (P.Eng.) because it prevents him from applying to work as a draftsman. Both believe that most newcomers are scared, and don't know how to apply their skills. One such 
newcomer, also present at that focus group, was a Bosnian physician who concludes that if not allowed to work as a physician in Canada, that she would rather not work in any related medical field; so as to not suffer the consequent humiliation of not being a physician in that workplace.

In contrast, JIAS and particularly JFS agencies, do not share the ardent attitude toward employment expressed by immigrants in focus groups. What is looked after first are basic needs: food, shelter, security, health. Jobs are considered important, but are not what these organisations follow as a guiding principle. In some rare instances agencies are quite successful in finding jobs for clients, though clients note that these tend to be manual labour and are therefore not so desirable.

There are distinctive qualifications that help newcomers into the workplace. A primary one is to have a recognised certification. As important is how well newcomers learn English. Some cities may be more closed than others to those for whom English is a second language. A client in Vancouver says, for example, that gaining employment is made more difficult by having an accent. Another client comments that practise in English can be facilitated through volunteering. Staff in Montreal add, with some frustration, how difficult it is to offer English courses in Quebec. While the Jewish community in Montreal is mostly English, the Provincial government does not provide funding to offer English courses.

In most JIAS related-agencies there is a lack of support for job services in the Jewish Community. What seems obvious, from travelling across the country, is that JFS agencies alone cannot provide the full range of services required for quality career counselling. If services are to improve universally, traditionally uninvolved members of the community will have to get involved in mentoring activities. The only alternative is to buy services from career counsellors rather than involving those of the Jewish community who are active in diverse areas of the economy, sometimes combined with having been a newcomer themselves.

More generally, immigrants comment that orientation information to introduce the working/office/employment culture in Canada would be helpful. This kind of a program, a client in Windsor feels, could be offered by former immigrants sharing insights into the differences between Canada and their homelands. "This person could unpack meaning, conventions, and the culture here with a focus to helping us understand and deal with the differences between there and here." A Toronto client reiterates and adds that forums could be held to introduce newcomers to prospective employers. In agreement, others from Winnipeg and Windsor add that they need to learn how to separate what they have to offer an employer from their personal selves so that they are not so distraught when rejected for employment.

Some newcomers have an orientation to starting small businesses which implies transcending fears associated with this activity. A more predominant view in entrepreneurial ventures, perhaps, is as one focus group agreed, "It is too early to consider starting a business. After being here for 10 years, and after taking business courses, maybe then running a business might be a possibility." Unfortunately, employment related programmes tend to be one of the first cut in times of fiscal restraint.

\section{Listening to Needs}

A sponsor in Edmonton-though I think it could have been anywherecommented "It would be helpful if JFS asked the question, 'What do you need in general?'" He continues, it is not that Canada is the epitome of a hard-core capitalist society, something that makes many from former socialist states twinge with anxiety. Instead, in Canada many things are free. In another focus group a sponsor in Winnipeg expresses her surprise with the welfare state. "There are many things for free here," she comments. She adds that educational materials explaining the differences between here and there (the former Soviet Union), and a book on services available to newcomers would be very useful.

Jewish Family Service and JIAS Agencies are noted for having responded to newcomers' needs with creative solutions. In Edmonton, for example, a synagogue held a mass wedding for nine Russian couples who had not before had a religious wedding. This same agency has recently started a singles group for Jewish newcomers who tend to be very isolated in the city. In Vancouver, staff speak among other needs to be able to tell people where to look for housing since Vancouver has become such an expensive city.

Outside of employment concerns the most stubborn of problems, of which those in focus groups speak, is sponsorship of parents. The number of people who would like to bring their parents constitutes a large group. Newcomers feel obliged to bring parents but receive no official support in this activity and bear total responsibility. Even with employment, caring for the financial concerns of their parents is a burden that seems too heavy for the average newcomer. Medical insurance is a daunting expense.

Sponsorship is more difficult when the newcomers are older. There is no hope that they will become financially independent. All that they worked for is left behind. What is worst, being sponsored tends to be hard on parents who experience an erosion of dignity "by knowing they are sitting on their children's support."

The difference in exchange rate, and the very high standard of living in Canada makes it very difficult to come to Canada as an immigrant, especially when head-taxes are applied. One young woman-who was employed within weeks after arriving in Ottawa-knows young Jews in her home country who are well qualified but cannot afford the processing fees the government is charging for immigration. She suggests that if the Jewish community wishes to grow that pro- 
viding loans for this purpose would be a good investment.

Some feel that there is a need for more staff. More than twice I heard from clients, or sponsors, that it would be beneficial to have a lawyer on staff for assistance in working with the government bureaucracy.

\section{Communities Welcoming Strangers}

The newcomers with whom I spoke wish to become part of the Canadian Jewish Community but report varying success in becoming accepted. There is a variety of experience, though most of the comments that I highlight are from Calgary and Winnipeg. In Calgary there is anger about the way the local community treats newcomers. An immigrant summed it with the following recount, "A Calgarian Jew said to me, 'Immigrants will never be accepted or recognised by the longer-term [Jewish] Community." Another said that in Calgary she is made to feel less than others because she does not have a strong religious tradition as do Calgarian Jews. Still another was shocked by how local Jews treat immigrant Jews. "It was very unequal." One person commented that the Jewish community could learn a lot from the Chinese community. "They have real community solidarity. In the Jewish community there is little help given to newcomers by others, especially jobs. As a result newcomers are underemployed."

Similar problems were mentioned in Winnipeg where not the meanness of the local community was mentioned, just the fact that community attention is being diverted from scriptural responsibilities-such as helping the stranger-in favour of building a new campus. Another commented, "We had a good network of friends soon after arriving. The Community helps us not to feel alienated. They are nice and decent." Yet, there is a sentiment, from the same person, that the Jewish community in Winnipeg is not very strong.

Speaking about first arrival in their communities, newcomers spoke of some of the things that happened, and their perceptions. Comments seemed to be filled with the contradictions with which they are faced. A newcomer in Vancouver, for example, questions whether or not the government wants them here? In Winnipeg, a staff person accompanies them to appointments and government offices in the beginning. In Toronto, there is a volunteer program where volunteers play this role. A staff person in Toronto says that they find that this program instigates the concept of voluntarism in the community. In other places newcomers are not accompanied to these initial appointments.

Sometimes it is difficult for the service provider to ensure that all relevant information is conveyed. As a test of clients' knowledge on types of housing, I found that participants rarely knew about co-operatives as a quality type of housing that would also introduce them to long-time Canadians. In Toronto participants did not know about the Metropolitan Toronto Volunteer Bureau which is essential to getting volunteer experience in one's chosen vocational field. In Vancouver a former teacher comments:

No one told us about a variety of things that we needed to know: how to get on a list for co-op housing, about child benefits; about how to become a substitute teacher and get a teaching certificate.

He had fortunately been able to find these things out himself and is now living in a co-operative while substitute teaching in a local school.

As for other organisations in the community, a lot was said about the synagogues. There tends to be a lack of coordination in a variety of places between synagogues themselves, and family service delivery agencies. Individual synagogues do not work together. Beyond concerns about coordination, there are general concerns in the experience of clients that arise from the expense of being a Jew. When asked about life cycle events, and what these events mean, newcomers embarrassingly comment about their high cost. Further, there is con- cern about the disparity, or unevenness, in how free space is allocated in synagogues for high holidays.

Generally, the experience of coming to Canada from Eastern Europe is very challenging. "There is a loss of identity when you arrive here. You are nothing", comments a woman in Vancouver. To make things worse, before coming they never realised how tough it is to make a living in Canada. A newcomer from Winnipeg builds on describing this experience and elaborates on the difference between here and there:

The culture is different here as compared to Eastern Europe. Here it is individualistic, there emphasis is on comrades. Here people let you make mistakes, let you fail. They expect that you will do things for yourself. They feel that it should be no easier here for you than for anybody else. Here people work very hard for their living.

Being involved in community can often make life seem easier. In many places staff estimate that 50 percent of newcomers are getting involved in the Jewish Community. A universal problem, however, is that they do not tend to be giving back to the community through volunteering. Part of the reticence about getting involved has to do with feeling like they do not measureup religiously. Besides not feeling good about themselves, because they have not received religious training, there is also a myth that it is too late to become more religiously Jewish. A man in Windsor comments, "Some of us did not receive religious training, but it does not matter so much because for us, it is a little too late. It is good for the children."

\section{Conclusion}

JIAS is grappling with how to offer services equitably across Canada; a goal attempted only by the federal government. No other non-governmental organisation in Canada comes close to the sophistication and ambition of the Jewish community in its attempt to offer services equitably across the country. This research and that 
which precedes it suggests that coming to a stage where a common language exists to assess equity of service is an expensive task that lies ahead.

As a non-Jew looking in on the laws pertinent to treating foreign aliens among the Jewish community, it seems that for what is accomplished in helping newcomers the community should be joyful. The Canadian Jewish community does come up short doctrinally in their exclusive concern for Jewish immigrants. Some effort needs to be made to consider providing for newcomer non-Jews, as well as Jews. This is the Jewish tradition, but has been lost perhaps because of the contemporary situation of Jewish society. Instead of being autonomous, the Jewish community is a subset of a larger Canadian secular society. For this reason, it seems to make some sense to focus only on Jewish newcomers. However, there may be costs to this decision. III

Notes

1. Numbers originate from JIAS national office.

2. Board members from Toronto and Mon treal were not interviewed.

References

Canadian Council for Reform Judaism. 1994. Response to the Discussion Paper Agenda: Jobs and Growth Improving Social Security. Toronto: (photocopy). Davis, Susan. 1994. Transcription of a conversation held in her Toronto office. Judaica Encyclopaedia. 1972. "Strangers and Gentiles." Jerusalem: Macmillan.

Kage, Joseph. 1962. With Faith and Thanksgiving: the Story of Two Hundred Years of Jewish Immigration and Immigration Aid Effort in Canada, 1760-1960. Montreal: Eagle Publishing Co.

Jewish Immigrant Aid Society (JIAS). 1992. Raw data from survey of JIAS contracted offices. Toronto: (photocopy).

Linzer, Norman. 1990. "Talmudic and Ethical Approaches of Soviet Jewish Resettlement." Journal of Jewish communal Service: $A$ Quarterly of Professional Trends and Developments 67 (Winter): 118-23.

Morris, John. 1995. "Faith Based Agencies Serving Newcomers Across Canada," Social Sciences and Humanities post-doctoral research project. 0

\section{So That Russia be "Saved" Anti-Jewish Violence in Russia: Its Roots and Consequences}

\author{
By Tanya Basok \\ and Alexander \\ Torolltơ: York Lanes Press, 1993 ISBN1- \\ 55014-01Q-8;8.5x1161p; CON \$9.95
}

The growing popularity of ultra-nationalism and neo-Nazism in Europe and to some extentinNorth America is truly alarming, and this publication offers a perceptive analysis of the political trends in Russia and their implications for Russian Jews. It. provides an historical analysis of anti-Jewish violence in Russia and poses an important question: can those conditions which resulted in anti-Jewish pogroms at the turn of the century re-emerge today?

Dr. Basok and Dr. Benifandarguein this occasional paper that there is a number of clear indications of the popularity of the anti-Semitic and ultranationalistideas notorily among the masses and nationalist organizations but in the government as well.

Many of those who have been impoverished as a result of the "shock therapy" or who have grown extremely disillusioned with Yeltsin's reform policies, havebecom.eattractedto the solutions such as: getting rid of ethnic minorities, especially Jews, territorial expansion of the Russian federation to include the Jormer Soviet republics, the extension of the Russian sphere of influence in Europe and Central Asia, protection of Russian lands (e.g., the Kurile Islands) and the curbing of ethnic nationalism within the Russian federation. Basok and Benifand's insightful analysis is an excellent attempt to understand the rise of ultra-nationalism in Russia.

Availablefrom:

Studies

Centre for Refugee

Fax: (416) 736-5837

Emall:

refuge@yorku.ca

\section{Refuge}

Canada's Periodical on Refugees is published six times a year by the Centre for Refugee Studies. York University, Toronto.

$$
\text { Available from: }
$$

Centre for ReftageeStudies. York University Sqjte3 3.

y QrkLanes. 4700 Keele St. Toronto ON M3J iP3

Email: fuge@yorkU.ca

.http://www.y()rku.calresearchlcrs 